of the Department is that of acting as an adviser to the State on chemical matters, of taking part in international studies on the mass-movement of the sea from place to place, and of examining samples submitted by other Government departments. In addition to the principal laboratory at Clement's Inn Passage, other laboratories under the control of Sir Robert Robertson are the Custom House laboratory, and laboratories at the Geological Survey, at the Army Supply Depot at Deptford, at Park Royal, and at five seaports. The public thinks of these laboratories as places where a great deal of 'testing' is carried out; chemists, however, know that in addition they house a vigorous research organisation, only part of the work of which can, in the public interest, be published in the scientific journals as notable contributions to the common stock of chemical knowledge.

\section{Harrison's Chronometers at the Science Museum}

THE Admiralty has kindly lent to the Science Museum, South Kensington, all four of the pioneer marine timekeepers made by John Harrison between 1729 and 1759. With these instruments Harrison was the first to show that it was possible to construct a portable timekeeper which would keep sufficiently accurate time at sea to be of use in determining a vessel's longitude, and thus solved the problem of 'finding the longitude' which had baffled men of science and inventors for more than two hundred years. Harrison's instruments were the first balancewheel timekeepers to embody any kind of compensation for the effects of change of temperature. In all four of his instruments compensation is provided by varying the effective length of the balancespring, the mechanical details varying in the different individuals. In the first three timekeepers, the effect of the ship's motion is also compensated by employing two balance-wheels connected together by an ingenious but delicate system equivalent to a frictionless gearing; in the fourth chronometer, however, this system is abandoned in favour of a single small balance-wheel the angular acceleration of which is large compared to the stray accelerations due to the ship's motion. The first three chronometers are large clocks each weighing more than fifty pounds, but the fourth is much smaller, being essentially a large watch about five inches in diameter. All four instruments have been cleaned, repaired and put into working order by Lieut.-Commander R. T. Gould, and they are now on exhibition in the Museum, in going condition.

\section{National Park in Snowdonia}

Six months ago public interest in Snowdonia as a national park was revived by the offer made by Mr. C. Williams-Ellis to the National Trust of 300 acres near Nant Gwynant with covenants to preserve the rest of Hafod Lwyfog farm in its present condition, provided others would co-operate in taking further steps for the preservation of this beautiful area. Since then the Caernarvonshire County Council has taken active steps towards the preparation of a planning scheme covering the whole area. Now, through the generosity of an anonymous benefactor, a scheme has been formulated by the National Trust for the preservation of the Aberglaslyn Pass. The anonymous benefactor has provided the funds for the purchase from the Snowdon Mountain Railway, Ltd., of the east side of the pass, provided the Trust can secure the co-operation of the owners of the land on the west side. The owners of Plas Aberglaslyn on the west of the Pass and Mr. Clough WilliamsEllis as owner of a small area to the south have immediately agreed, and the National Trust is now confidently awaiting the assurances of one or two other contiguous owners before completing the purchase. It is further believed that another offer of land between Gwynant and Pont Aberglaslyn is likely to be made.

\section{Medical Botany of the Eighteenth Century}

Mr. H. S. REDGRove contributes an interesting article to the Gardeners' Chronicle of May 11 describing a very complete work on "Medical Botany, containing Systematic and General Descriptions, with Plates, of all the Medicinal Plants, indigenous and exotic, comprehended in the Catalogues of the Materia Medica, . . accompanied by a Circumstantial Detail of their Medicinal Effects, and of the Diseases in which they have been most successfully Employed". This remarkable work was from the pen of Dr. William Woodville (1752-1805). It was published first in monthly parts, but later in three volumes and a supplement (1790-94). Woodville's life is described briefly in the article under review, and his peculiar qualifications for the work are emphasised. One cannot but feel regret, as $\mathrm{Mr}$. Redgrove quotes passages from "Medical Botany", that such herbs as Potentilla erecta have passed from medicinal use, for their employment seems to have been determined by very exact knowledge. 210 drawings by Sowerby were included in the work, which was written in a thoroughly scientific spirit.

\section{Common Names for Plant Diseases}

DIFFICULTIES of expression by written word are great, even when words have exact literary meanings. The words of a new science like plant pathology have been coined by practical growers in different places and under varying conditions, so it is not a matter of wonder that much confusion has resulted. The second edition of the "List of Common Names of British Plant Diseases" (Cambridge: University Press. Pp. 95. 2s. 6d. net) represents a serious attempt to standardise nomenclature of disease symptoms and causal agents. It has been compiled by the Plant Pathology Committee of the British Mycological Society. The list is in two columnsfirst the common name and then the name of the parasite. Synonyms are given where necessary, but the volume is a well-regulated attempt to establish one name for each disease. Many synonyms are being discouraged, whilst in one or two cases fresh names have been introduced for the sake of clarity. The host plants are grouped conveniently into 